\title{
Does Left Atrial Appendage Amputation During Routine Cardiac Surgery Reduce Future Atrial Fibrillation and Stroke?
}

\author{
Helena Domínguez ${ }^{1,2} \cdot$ Christoffer Valdorff Madsen ${ }^{1} \cdot$ Oliver Nøhr Hjorth Westh ${ }^{1} \cdot$ Peter Appel Pallesen ${ }^{3}$. \\ Christian Lildal Carrranza ${ }^{4} \cdot$ Akhmadjon Irmukhamedov $^{3}$. Jesper Park-Hansen ${ }^{1,2}$
}

Published online: 31 August 2018

(C) The Author(s) 2018

\begin{abstract}
Purpose of Review Stroke is the most feared complication of atrial fibrillation. To prevent stroke, left atrial appendage exclusion has been targeted, as it is the prevalent site for formation of heart thrombi during atrial fibrillation.

We review the historic development of methods for exclusion of the left atrial appendage and the evidence to support its amputation during routine cardiac surgery.

Recent Findings Evidence is not yet sufficient to routinely recommend left atrial exclusion during heart surgery, despite a high prevalence of postoperative atrial fibrillation. Observational studies indicate that electrical isolation of scarring from clip or suture techniques reduces the arrhythmogenic substrate.

Summary Randomized studies comparing different methods of closure of the left atrial appendage before amputation do not exist. Such studies are therefore warranted, as well as studies that can elucidate whether amputation is superior to leaving the left atrial appendage stump. Potentially, thrombogenic remaining pouch after closure should be addressed.
\end{abstract}

Keywords Left atrial appendage $\cdot$ Cardiac surgery $\cdot$ Atrial fibrillation $\cdot$ Thromboembolism $\cdot$ Stroke
Abbreviations
AF Atrial fibrillation
LA Left atrium
LAA Left atrial appendage
OAC Oral anti-coagulants
TEE Trans-esophageal echocardiography

This article is part of the Topical Collection on Invasive Electrophysiology and Pacing

Helena Domínguez

mdom0002@ regionh.dk

Christoffer Valdorff Madsen

Christoffer.valdorff.madsen@ regionh.dk

Oliver Nøhr Hjorth Westh

hts772@alumni.ku.dk

Peter Appel Pallesen

peter.pallesen@rsyd.dk

Christian Lildal Carrranza

christian.lildal.carranza@ regionh.dk

Akhmadjon Irmukhamedov

akhmadjon.irmukhamedov@rsyd.dk

\section{Introduction}

Does left atrial appendage (LAA) amputation during routine cardiac surgery reduce the risk of stroke and future atrial fibrillation? This question has been posed for more than 150 years $[1,2]$, since the LAA is recognized as the prevalent site for formation of thrombi during atrial fibrillation (AF)

Jesper Park-Hansen

Jesper.park.hansen@ regionh.dk

1 Department of Cardiology, Bispebjerg-Frederiksberg University Hospital, Nordre Fasanvej 57, vej 4, Building 3, 3rd Floor, DK-2000 Frederiksberg, Denmark

2 Department of Biomedicine, University of Copenhagen, Blegdamsvej 3B, Panum Building 10.5, DK-2400 Copenhagen, Denmark

3 Department of Heart, Lung and Vascular Surgery, Odense University Hospital, Sdr. Boulevard 29, DK-5000 Odense, Denmark

4 Department of Cardio-thoracic Surgery, Blegdamsvej 9, 2100 København, Copenhagen, Rigshospitalet, Denmark 
[3-5], with stroke being its most common and potentially devastating thromboembolic complication.

\section{Atrial Fibrillation and Its Relation to Open-heart Surgery}

Occurrence of AF following cardiac surgery is common, with a prevalence of 10 to $65 \%$ [6-8], and is associated with prolonged hospitalization and higher risk of mortality [7-10].

Paroxysmal AF after cardiac surgery is often self-limiting [11], and up to $40 \%$ of patients with $\mathrm{AF}$ are asymptomatic during the arrhythmia [12]. Hence, many patients with unrecognized recurrent $\mathrm{AF}$, who do not receive anti-coagulation after surgery, remain at risk for stroke [13]. This is a growing problem since more elderly patients undergo cardiac surgery [14]. Although the risk of complications during surgery is improving, patients continue to have a high risk of stroke if they have AF $[15,16]$. Therefore, multiple approaches are targeted to relieve this burden. That is, to prevent the occurrence of $\mathrm{AF}[17,18]$ and its recurrence after surgery [19-21], and, to reduce the thrombogenic substrate, the left atrial appendage (LAA) is excluded [22-24]. Oral anti-coagulation $(\mathrm{OAC})$ is an efficient method for thromboembolism risk reduction [25]. However, the adequate length of OAC after postoperative AF is still unknown $[18,26]$. Importantly, between 30 and $50 \%$ of patients are not eligible for OAC due to high risk of bleeding or other contraindications [25, 27]. Furthermore, it is estimated that $16-50 \%$ of patients in OAC therapy are not sufficiently anti-coagulated [28-30]. In these patients a highly reliable LAA occlusion would be an attractive alternative as it potentially reduces stroke risk by $50 \%$ [31].

\section{The Left Atrial Appendage and Thrombus Formation}

The LAA is a hook-like diverticulum of the left atrium (LA) consisting of one or more lobes with a trabeculated wall due to parallel-running pectinate muscles [32, 33]. In sinus rhythm, the LAA is highly contractile (contracts from its apex toward the base) and the blood flow within the lumen is sufficient to avoid thrombus formation. Contrarily, during AF, the contractility of the LAA is limited and the blood flow within the lumen is reduced creating a hemodynamic 'dead-space' [34, 35]. Furthermore, the highly trabeculated wall of the LAA plays an important role in its high thrombogenicity, and increased thrombus formation occurs with smaller LAA orifice and higher number of lobes [36, 37]. Therefore, the LAA is considered the primary source of cardio-embolic stroke in patients with non-valvular AF $[25,38]$, although thrombi can develop outside the LAA [3]. Accordingly, transesophageal echocardiography (TEE) is the key examination for diagnosing thrombus formation in the LAA $[35,37,39]$, and direct current conversion to sinus rhythm has proved to be safe in the absence of thrombi in the LAA during TEE [33, 34, 40-42].

\section{Historic Perspective on Amputation of the Left Atrial Appendage During Surgery}

The first amputations of the LAA in humans [43] were reported almost simultaneously with the results of the procedure in animal experiments [44-46]. After these successful pioneering attempts, they were subsequently performed in addition to mitral commissurotomy, to alleviate the well-known high thrombogenicity in mitral stenosis [38, 47, 48]. Systematic exclusion of the LAA is currently recommended in addition to surgical ablation procedures [21].

Thoracoscopic amputations of the LAA were initially performed by Johnson et al. as a stand-alone procedure in patients with high risk for thromboembolisms, who do not tolerate OAC [25]. Since then, there have been developed minimally invasive approaches to amputate the LAA [19, 49-53]. Nevertheless, the development of safe and effective clip devices for obliteration of the LAA thoracoscopically [54] and intra-operatively [55••, 56], is emerging as a preferred method compared to LAA amputation $[57,58]$.

\section{Less Arrhythmogenic Substrate After LAA Exclusion}

Persistent AF can originate from the LAA [59] and it has been demonstrated that targeting ablation of the LAA can reduce AF $[21,60]$. Therefore, exclusion of the LAA can possibly provide an anti-arrhythmogenic effect, in addition to protection against thromboembolisms. Accordingly, a reduction of atrial dispersion has been demonstrated with LAA ligation in patients with AF [61]. Additionally, clip occlusion [62] and epicardial ligation [63] have shown to provide electric appendage isolation. In a recent study, patients randomized to closure or not closure of the LAA during cardiac surgery, closure by epicardial suture seemed to reduce AF during follow-up (Park-Hansen in press). It is conceivable that amputation of the LAA can have a similar anti-arrhythmogenic effect, but such an effect remains to be studied.

\section{Hemodynamic Consequences of LAA Amputation}

Natriuretic hormones can be secreted from all myocytes but, in normal healthy conditions they are primarily produced in the LAA [64-67]. Levels of natriuretic hormones are elevated in permanent $\mathrm{AF}[68]$ and, specially, levels of B-type natriuretic peptide reveal paroxysms after ablation [69-73].

The first successful LAA amputations on healthy dogs in the 1940s [1] were followed by concerns on possible impairment of mechanisms to compensate fluid overload, due to the loss of atrium natriuretic peptides and a reduced stroke volume of the left atrium [44-46]. Despite these concerns, 
experimental observations in animals do not seem to have clinical importance in humans [74].

Recently, it has been raised concern by the observation that, along with a decrease on the left atrium volume that follows successful AF ablation, there is an increase in the LAA volume, assessed with magnetic resonance scanning [75]. This is a matter of concern, since larger LAA volume increases the risk of stroke in patients with comparable thromboembolic risk profile [76, 77].

In a recent study, no hemodynamic changes have been observed immediately after percutaneous LAA closure [78]. Nevertheless, it seems to be important whether the LAA is closed from the endocardial or from the epicardial site, since comparing the two approaches, only the epicardial closure proved beneficial hemodynamic changes [79].

According to these observations, an epicardial closure, with or without subsequent amputation, should be the preferred approach.

\section{Thrombogenicity After Amputation of the LAA}

The thrombogenicity of the LAA during AF is, in part, attributable to loss of contractility of the LAA. In a retrospective study of patients who underwent occlusion of the LAA, those with preserved LAA had a better contractility estimated with echocardiography, compared with a group where the LAA was amputated; however, this difference did not preclude differences on stroke nor occurrence of AF [80].
Regardless of the LAA exclusion method, the potential thrombogenicity of the remaining appendage pouch is a matter of major concern $[31,81 \bullet, 82]$. In a previous nonrandomized study that compared efficacy of several methods of LAA closure, TEE reveled a remnant LAA in $26 \%$ of patients. Importantly, $12 \%$ of these patients had suffered strokes in the lapse from the operation to the time when TEE was performed, despite none having clots in the remnant LAA [83]. In early studies on excision of the LAA after stapling, additional sutures were necessary to repair tears $[84$, 85], and similar complications with tears needing repair have also been reported more recently in the LAAOS-II trial [86]. Furthermore, intuitively, an irregular endocardial surface after suture (Fig. 1a) may be more thrombogenic than a smoother surface observable after epicardial stapling (Fig. 1b) and after epicardial clips (Fig. 1c) or snaring (Fig. 1d). Assuming the size of the remaining pouch is important for its thrombogenicity, perioperative TEE could serve for assessing its size, and perioperatively, limit the size of the pouch for example to less than $1 \mathrm{~cm}$, by performing an additional suture or stapler line, or placing an additional clip when needed.

\section{Conclusion}

Several studies support a beneficial effect of LAA closure during surgery, but evidence is not yet sufficient to support closure of the LAA systematically in addition to heart surgery,
Fig. 1 View of the endocardial surface of the left atrium, after LAA exclusion with: suture marked with white arrows, the black arrows show the circumflex coronary artery a, epicardial stapling (b), clips (c), or epicardial snoring, with a black arrow showing the endocardial surface (d). LAA left atrium appendage. (Figure 1a is reproduced from Aoyagi S. et al. Heart, Lung and Circulation, 2017.26:413-15, with permission from Elsevier; [87].) (Figure 1c is kindly provided by AtriCure Inc.) (Figure 1d is reproduced from Bartus K et al. Circ Arrhythm Electrophysiol. 2014;7:764-767, with permission; [88])
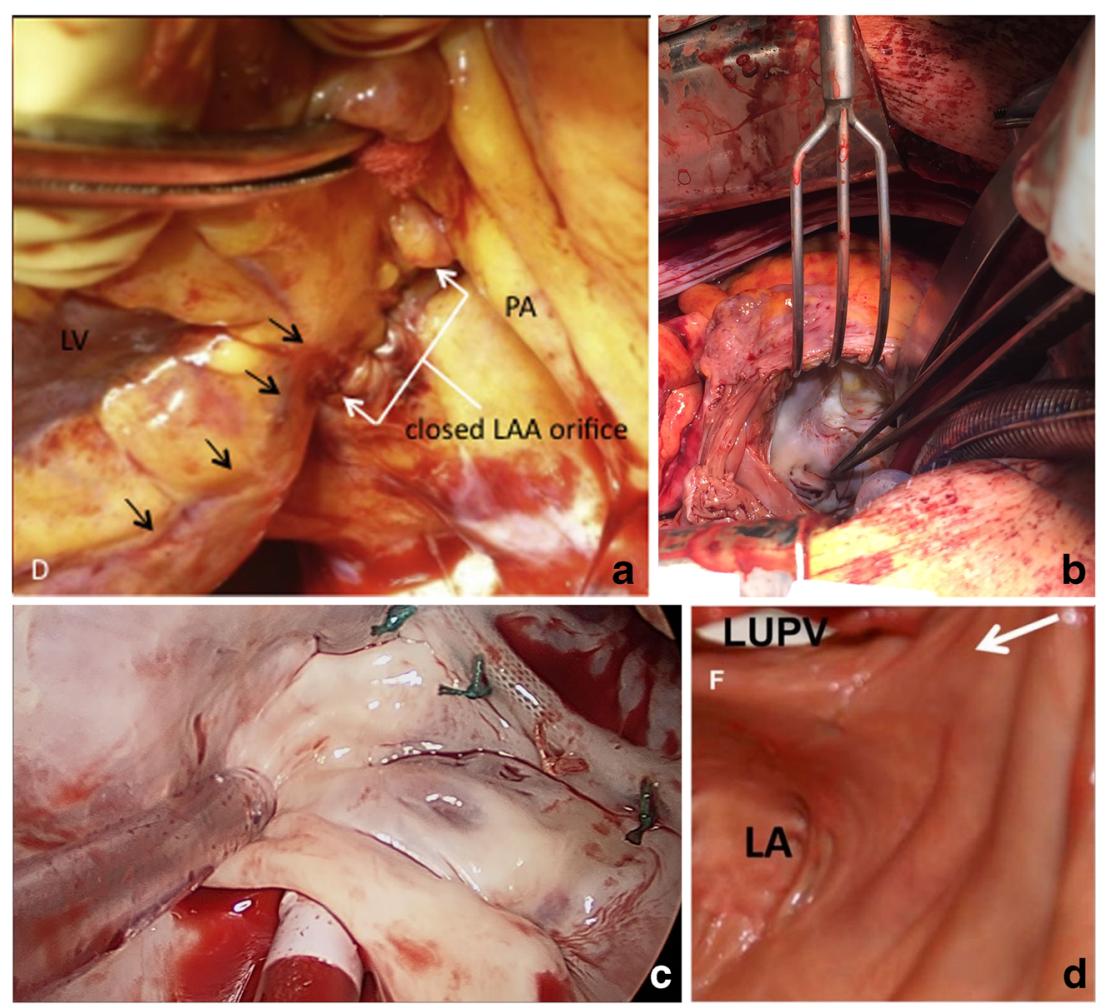
to protect against thromboembolisms related to AF. Hence, there is a need for randomized studies to provide the evidence of stroke protection and, furthermore, comparing different methods for closure of the LAA in terms of arrhythmogenic impact. Such studies should address how to manage the potential thromboembolic problem of a remaining pouch after LAA closure, to elucidate what is the optimal management of the LAA during surgery.

\section{Compliance with Ethical Standards}

Conflict of Interest Helena Domínguez, Christoffer Valdorff Madsen, Oliver Nøhr Hjorth Westh, Peter Appel Pallesen, Christian Lildal Carrranza, Akhmadjon Irmukhamedov, and Jesper Park-Hansen declare that they have no conflict of interest.

Human and Animal Rights and Informed Consent This article does not contain any studies with human or animal subjects performed by any of the authors.

Open Access This article is distributed under the terms of the Creative Commons Attribution 4.0 International License (http:// creativecommons.org/licenses/by/4.0/), which permits unrestricted use, distribution, and reproduction in any medium, provided you give appropriate credit to the original author(s) and the source, provide a link to the Creative Commons license, and indicate if changes were made.

\section{References}

Papers of particular interest, published recently, have been highlighted as:

•• Of major Importance

1. Hellerstein HK, Sinaiko E, Dolgin M. Amputation of the canine atrial appendages. Proc Soc Exp Biol Med. 1947;66(2):337.

2. Castella M. The new 2016 European Society of Cardiology/ European Association for Cardio-Thoracic Surgery Guidelines: enough guidance? enough evidence? Eur J Cardiothorac Surg. 2018;53(suppl_1):i9-i13.

3. Mahajan R, Brooks AG, Sullivan T, Lim HS, Alasady M, Abed HS, et al. Importance of the underlying substrate in determining thrombus location in atrial fibrillation: implications for left atrial appendage closure. Heart. 2012;98(15):1120-6.

4. Aberg H. Atrial fibrillation. II. A study of fibrillatory wave size on the regular scalar electrocardiogram. Acta Med Scand. 1969;185(5):381-5.

5. Tsai LM, Lin LJ, Teng JK, Chen JH. Prevalence and clinical significance of left atrial thrombus in nonrheumatic atrial fibrillation. Int J Cardiol. 1997;58(2):163-9.

6. Rho RW. The management of atrial fibrillation after cardiac surgery. Heart. 2009;95(5):422-9.

7. Mathew JP, Fontes ML, Tudor IC, Ramsay J, Duke P, Mazer CD, et al. A multicenter risk index for atrial fibrillation after cardiac surgery. JAMA. 2004;291(14):1720-9.

8. Maesen B, Nijs J, Maessen J, Allessie M, Schotten U. Postoperative atrial fibrillation: a maze of mechanisms. Europace. 2012;14(2):159-74.
9. Ahlsson A, Fengsrud E, Bodin L, Englund A. Postoperative atrial fibrillation in patients undergoing aortocoronary bypass surgery carries an eightfold risk of future atrial fibrillation and a doubled cardiovascular mortality. Eur J Cardiothorac Surg. 2010;37(6): 1353-9.

10. Saxena A, Dinh D, Dimitriou J, Reid C, Smith J, Shardey G, et al. Preoperative atrial fibrillation is an independent risk factor for midterm mortality after concomitant aortic valve replacement and coronary artery bypass graft surgery. Interact Cardiovasc Thorac Surg. 2013;16(4):488-94.

11. Kowey PR, et al. Clinical outcome of patients who develop PAF after CABG surgery. Pacing Clin Electrophysiol. 2001;24(2):1913.

12. Healey JS, Connolly SJ, Gold MR, Israel CW, van Gelder I, Capucci A, et al. Subclinical atrial fibrillation and the risk of stroke. N Engl J Med. 2012;366(2):120-9.

13. Almahameed ST, et al. Left atrial appendage exclusion and the risk of thromboembolic events following mitral valve surgery. J Cardiovasc Electrophysiol. 2007;18(4):364-6.

14. Tarakji KG, Sabik JF 3rd, Bhudia SK, Batizy LH, Blackstone EH. Temporal onset, risk factors, and outcomes associated with stroke after coronary artery bypass grafting. JAMA. 2011;305(4):381-90.

15. Zoni-Berisso M, Lercari F, Carazza T, Domenicucci S. Epidemiology of atrial fibrillation: European perspective. Clin Epidemiol. 2014;6:213-20.

16. Chugh SS, Havmoeller R, Narayanan K, Singh D, Rienstra M, Benjamin EJ, et al. Worldwide epidemiology of atrial fibrillation: a global burden of disease 2010 study. Circulation. 2014;129(8): 837-47.

17. Burgess DC, Kilborn MJ, Keech AC. Interventions for prevention of post-operative atrial fibrillation and its complications after cardiac surgery: a meta-analysis. Eur Heart J. 2006;27(23):2846-57.

18. Frendl G, Sodickson AC, Chung MK, Waldo AL, Gersh BJ, Tisdale JE, et al. 2014 AATS guidelines for the prevention and management of perioperative atrial fibrillation and flutter for thoracic surgical procedures. J Thorac Cardiovasc Surg. 2014;148(3):e153-93.

19. Gillinov AM. Advances in surgical treatment of atrial fibrillation. Stroke. 2007;38(2 Suppl):618-23.

20. Saltman AE, Gillinov AM. Surgical approaches for atrial fibrillation. Cardiol Clin. 2009;27(1):179-88. x

21. Badhwar V, Rankin JS, Damiano RJ Jr, Gillinov AM, Bakaeen FG, Edgerton JR, et al. The Society of Thoracic Surgeons 2017 clinical practice guidelines for the surgical treatment of atrial fibrillation. Ann Thorac Surg. 2017;103(1):329-41.

22. Onalan O, Crystal E. Left atrial appendage exclusion for stroke prevention in patients with nonrheumatic atrial fibrillation. Stroke. 2007;38(2 Suppl):624-30.

23. Caliskan, E., et al. Epicardial left atrial appendage AtriClip occlusion reduces the incidence of stroke in patients with atrial fibrillation undergoing cardiac surgery. Europace. 2017.

24. Melduni RM, Schaff HV, Lee HC, Gersh BJ, Noseworthy PA, Bailey KR, et al. Impact of left atrial appendage closure during cardiac surgery on the occurrence of early postoperative atrial fibrillation, stroke, and mortality: a propensity score-matched analysis of 10633 patients. Circulation. 2017;135(4):366-78.

25. Johnson WD, Ganjoo AK, Stone CD, Srivyas RC, Howard M. The left atrial appendage: our most lethal human attachment! Surgical implications. Eur J Cardiothorac Surg. 2000;17(6):718-22.

26. Kirchhof P, et al. 2016 ESC Guidelines for the Management of Atrial Fibrillation Developed in Collaboration With EACTS. Rev Esp Cardiol (Engl Ed). 2017;70(1):50.

27. Kirchhof P, Ammentorp B, Darius H, de Caterina R, le Heuzey JY, Schilling RJ, et al. Management of atrial fibrillation in seven European countries after the publication of the 2010 ESC guidelines on atrial fibrillation: primary results of the PREvention oF 
thromboemolic events-European registry in atrial fibrillation (PREFER in AF). Europace. 2014;16(1):6-14.

28. Waldo AL, Becker RC, Tapson VF, Colgan KJ, NABOR Steering Committee. Hospitalized patients with atrial fibrillation and a high risk of stroke are not being provided with adequate anticoagulation. J Am Coll Cardiol. 2005;46(9):1729-36.

29. Ogilvie IM, Newton N, Welner SA, Cowell W, Lip GYH. Underuse of oral anticoagulants in atrial fibrillation: a systematic review. Am J Med. 2010;123(7):638-645 e4.

30. Brown MT, Bussell JK. Medication adherence: WHO cares? Mayo Clin Proc. 2011;86(4):304-14.

31. Chatterjee S, Alexander JC, Pearson PJ, Feldman T. Left atrial appendage occlusion: lessons learned from surgical and transcatheter experiences. Ann Thorac Surg. 2011;92(6):2283-92.

32. Kerut EK. Anatomy of the left atrial appendage. Echocardiography. 2008;25(6):669-73.

33. Barbero U, Ho SY. Anatomy of the atria: a road map to the left atrial appendage. Herzschrittmacherther Elektrophysiol. 2017;28(4): 347-54.

34. Pollick C, Taylor D. Assessment of left atrial appendage function by transesophageal echocardiography. Implications for the development of thrombus. Circulation. 1991;84(1):223-31.

35. Beigel R, Wunderlich NC, Ho SY, Arsanjani R, Siegel RJ. The left atrial appendage: anatomy, function, and noninvasive evaluation. $\mathrm{J}$ Am Coll Cardiol Img. 2014;7(12):1251-65.

36. Di Biase L, et al. Does the left atrial appendage morphology correlate with the risk of stroke in patients with atrial fibrillation? Results from a multicenter study. J Am Coll Cardiol. 2012;60(6):531-8.

37. Khurram IM, Dewire J, Mager M, Maqbool F, Zimmerman SL, Zipunnikov V, et al. Relationship between left atrial appendage morphology and stroke in patients with atrial fibrillation. Heart Rhythm. 2013;10(12):1843-9.

38. Blackshear JL, Odell JA. Appendage obliteration to reduce stroke in cardiac surgical patients with atrial fibrillation. Ann Thorac Surg. 1996;61(2):755-9.

39. Malik SB, Kwan D, Shah AB, Hsu JY. The right atrium: gateway to the heart-anatomic and pathologic imaging findings. Radiographics. 2015;35(1):14-31.

40. Grimm RA, Stewart WJ, Black IW, Thomas JD, Klein AL. Should all patients undergo transesophageal echocardiography before electrical cardioversion of atrial fibrillation? J Am Coll Cardiol. 1994;23(2):533-41.

41. Shen X, Li H, Rovang K, Hee T, Holmberg MJ, Mooss AN, et al. Transesophageal echocardiography before cardioversion of recurrent atrial fibrillation: does absence of previous atrial thrombi preclude the need of a repeat test? Am Heart J. 2003;146(4):741-5.

42. Smith SA, Binkley PF, Foraker RE, Nagaraja HN, Orsinelli DA. The role of repeat transesophageal echocardiography in patients without atrial thrombus prior to cardioversion or ablation. J Am Soc Echocardiogr. 2012;25(10):1106-12.

43. Madden JL. Resection of the left auricular appendix; a prophylaxis for recurrent arterial emboli. J Am Med Assoc. 1949;140(9):76972.

44. Stewart JM, Dean R, Brown M, Diasparra D, Zeballos GA, Schustek M, et al. Bilateral atrial appendectomy abolishes increased plasma atrial natriuretic peptide release and blunts sodium and water excretion during volume loading in conscious dogs. Circ Res. 1992;70(4):724-32.

45. Benjamin BA, Metzler CH, Peterson TV. Chronic atrial appendectomy alters sodium excretion in conscious monkeys. Am J Phys. 1988;254(4 Pt 2):R699-705.

46. Massoudy P, Beblo S, Raschke P, Zahler S, Becker BF. Influence of intact left atrial appendage on hemodynamic parameters of isolated Guinea pig heart. Eur J Med Res. 1998;3(10):470-4.
47. Bailey CP, et al. Commissurotomy for mitral stenosis; technique for prevention of cerebral complications. J Am Med Assoc. 1952;149(12):1085-91.

48. Belcher JR, Somerville W. Systemic embolism and left auricular thrombosis in relation to mitral valvotomy. Br Med J. 1955;2(4946):1000-3.

49. Matsutani N, Takase B, Ozeki Y, Maehara T, Lee R. Minimally invasive cardiothoracic surgery for atrial fibrillation: a combined Japan-US experience. Circ J. 2008;72(3):434-6.

50. Syed TM, Halperin JL. Left atrial appendage closure for stroke prevention in atrial fibrillation: state of the art and current challenges. Nat Clin Pract Cardiovasc Med. 2007;4(8):428-35.

51. Yilmaz A, Geuzebroek GSC, van Putte BP, Boersma LVA, Sonker U, de Bakker JMT, et al. Completely thoracoscopic pulmonary vein isolation with ganglionic plexus ablation and left atrial appendage amputation for treatment of atrial fibrillation. Eur J Cardiothorac Surg. 2010;38(3):356-60.

52. Yilmaz A, Van Putte BP, Van Boven WJ. Completely thoracoscopic bilateral pulmonary vein isolation and left atrial appendage exclusion for atrial fibrillation. J Thorac Cardiovasc Surg. 2008;136(2): $521-2$.

53. Inoue T, Suematsu Y. Left atrial appendage resection can be performed minimally invasively with good clinical and echocardiographic outcomes without any severe risk. Eur J Cardiothorac Surg. 2018;54:78-83.

54. Suwalski P, Witkowska A. Totally thoracoscopic left atrial occlusion concomitant to endoscopic atraumatic coronary artery bypass grafting (EACAB). Multimed Man Cardiothorac Surg. 2018;2018.

$55 . \bullet$ Lee $\mathrm{R}$, et al. A randomized, prospective pilot comparison of 3 atrial appendage elimination techniques: Internal ligation, stapled excision, and surgical excision. J Thorac Cardiovasc Surg. 2016;152(4): 1075-80. This study compares three atrial appendage exclusion techniques in a randomized trial. Such kind of studies are needed to evaluate what techniques can provide the best effects and the least complications.

56. Ailawadi G, et al. Exclusion of the left atrial appendage with a novel device: early results of a multicenter trial. J Thorac Cardiovasc Surg. 2011;142(5):1002-9. 1009 e1

57. Emmert MY, Puippe G, Baumüller S, Alkadhi H, Landmesser U, Plass A, et al. Safe, effective and durable epicardial left atrial appendage clip occlusion in patients with atrial fibrillation undergoing cardiac surgery: first long-term results from a prospective device trial. Eur J Cardiothorac Surg. 2014;45(1):126-31.

58. Khan HR, Kralj-Hans I, Haldar S, Bahrami T, Clague J, de Souza $\mathrm{A}$, et al. Catheter ablation versus thoracoscopic surgical ablation in long standing persistent atrial fibrillation (CASA-AF): study protocol for a randomised controlled trial. Trials. 2018;19(1):117.

59. Di Biase L, Santangeli P, Natale A. How to ablate long-standing persistent atrial fibrillation? Curr Opin Cardiol. 2013;28(1):26-35.

60. Di Biase L, et al. Left atrial appendage isolation in patients with longstanding persistent AF undergoing catheter ablation: BELIEF trial. J Am Coll Cardiol. 2016;68(18):1929-40.

61. Kawamura M, Scheinman MM, Lee RJ, Badhwar N. Left atrial appendage ligation in patients with atrial fibrillation leads to a decrease in atrial dispersion. J Am Heart Assoc. 2015;4(5).

62. Starck CT, Steffel J, Emmert MY, Plass A, Mahapatra S, Falk V, et al. Epicardial left atrial appendage clip occlusion also provides the electrical isolation of the left atrial appendage. Interact Cardiovasc Thorac Surg. 2012;15(3):416-8.

63. Afzal MR, Kanmanthareddy A, Earnest M, Reddy M, Atkins D, Bommana S, et al. Impact of left atrial appendage exclusion using an epicardial ligation system (LARIAT) on atrial fibrillation burden in patients with cardiac implantable electronic devices. Heart Rhythm. 2015;12(1):52-9.

64. Tabata T, Oki T, Yamada H, Abe M, Onose Y, Thomas JD. Relationship between left atrial appendage function and plasma 
concentration of atrial natriuretic peptide. Eur J Echocardiogr. 2000;1(2):130-7.

65. Goetze JP, Friis-Hansen L, Rehfeld JF, Nilsson B, Svendsen JH. Atrial secretion of B-type natriuretic peptide. Eur Heart J. 2006;27(14):1648-50.

66. Hamid Q, Wharton J, Terenghi G, Hassall CJ, Aimi J, Taylor KM, et al. Localization of atrial natriuretic peptide mRNA and immunoreactivity in the rat heart and human atrial appendage. Proc Natl Acad Sci U S A. 1987;84(19):6760-4.

67. Leinonen JV, Emanuelov AK, Platt Y, Helman Y, Feinberg Y, Lotan $\mathrm{C}$, et al. Left atrial appendages from adult hearts contain a reservoir of diverse cardiac progenitor cells. PLoS One. 2013;8(3):e59228.

68. Rossi A, Enriquez-Sarano M, Burnett JC Jr, Lerman A, Abel MD, Seward JB. Natriuretic peptide levels in atrial fibrillation: a prospective hormonal and Doppler-echocardiographic study. J Am Coll Cardiol. 2000;35(5):1256-62.

69. Hussein AA, Saliba WI, Martin DO, Shadman M, Kanj M, Bhargava $\mathrm{M}$, et al. Plasma B-type natriuretic peptide levels and recurrent arrhythmia after successful ablation of lone atrial fibrillation. Circulation. 2011;123(19):2077-82.

70. Giannopoulos G, Kossyvakis C, Angelidis C, Efremidis M, Panagopoulou V, Letsas K, et al. Amino-terminal B-natriuretic peptide levels and postablation recurrence in hypertensive patients with paroxysmal atrial fibrillation. Heart Rhythm. 2015;12(7):1470-5.

71. Degener S, Pattberg SV, Feuersenger H, Bansmann PM, Shin DI, Krummenauer F, et al. Predictive value of B-type natriuretic peptide levels in patients with paroxysmal and persistent atrial fibrillation undergoing pulmonary vein isolation. J Interv Card Electrophysiol. 2011;30(3):217-25.

72. Yamada T, Murakami Y, Okada T, Okamoto M, Shimizu T, Toyama $\mathrm{J}$, et al. Plasma atrial natriuretic peptide and brain natriuretic peptide levels after radiofrequency catheter ablation of atrial fibrillation. Am J Cardiol. 2006;97(12):1741-4.

73. Ma XX, Zhang YL, Hu B, Jiang WJ, Wang M, Zheng DY, et al. Association between left atrial appendage emptying velocity, Nterminal plasma brain natriuretic peptide levels, and recurrence of atrial fibrillation after catheter ablation. J Interv Card Electrophysiol. 2017;48(3):343-50.

74. Al-Saady NM, Obel OA, Camm AJ. Left atrial appendage: structure, function, and role in thromboembolism. Heart. 1999;82(5): 547-54.

75. Kim YG, Shim J, Oh SK, Park HS, Lee KN, Hwang SH, et al. Different responses of left atrium and left atrial appendage to radiofrequency catheter ablation of atrial fibrillation: a follow up MRI study. Sci Rep. 2018;8(1):7871.

76. Lee JM, Kim JB, Uhm JS, Pak HN, Lee MH, Joung B. Additional value of left atrial appendage geometry and hemodynamics when considering anticoagulation strategy in patients with atrial fibrillation with low CHA2DS2-VASc scores. Heart Rhythm. 2017;14(9): 1297-301
77. Chen Z, Bai W, Li C, Wang H, Tang H, Qin Y, et al. Left atrial appendage parameters assessed by real-time three-dimensional transesophageal echocardiography predict thromboembolic risk in patients with nonvalvular atrial fibrillation. J Ultrasound Med. 2017;36(6):1119-28.

78. Asmarats L, Bernier M, O'Hara G, Paradis JM, O'Connor K, Beaudoin J, Bilodeau, S., Cavalcanti, R., Champagne, J. and Rodes-Cabau, J. Hemodynamic impact of percutaneous left atrial appendage closure in patients with paroxysmal atrial fibrillation. J Interv Card Electrophysiol. 2018. https://doi.org/10.1007/s10840018-0387-2

79. Lakkireddy D, Turagam M, Afzal MR, Rajasingh J, Atkins D, Dawn B, et al. Left atrial appendage closure and systemic Homeostasis: the LAA HOMEOSTASIS study. J Am Coll Cardiol. 2018;71(2):135-44.

80. Lee CH, Kim JB, Jung SH, Choo SJ, Chung CH, Lee JW. Left atrial appendage resection versus preservation during the surgical ablation of atrial fibrillation. Ann Thorac Surg. 2014;97(1):124-32.

81.• Aryana A, et al. Association between incomplete surgical ligation of left atrial appendage and stroke and systemic embolization. Heart Rhythm. 2015;12(7):1431-7. This study shows the importance of achieving complete closure of the left atrium appendage with surgery, to avoid an increased risk of thromboembolisms.

82. Ventosa-Fernandez G, Quintana E, Castellá M, Pereda D. Exclusion of the left atrial appendage with the TigerPaw II system: a word of caution. Interact Cardiovasc Thorac Surg. 2015;21(6):803-4.

83. Kanderian AS, Gillinov AM, Pettersson GB, Blackstone E, Klein AL. Success of surgical left atrial appendage closure: assessment by transesophageal echocardiography. J Am Coll Cardiol. 2008;52(11):924-9.

84. Gillinov AM, Pettersson G, Cosgrove DM. Stapled excision of the left atrial appendage. J Thorac Cardiovasc Surg. 2005;129(3):67980 .

85. Healey JS, Crystal E, Lamy A, Teoh K, Semelhago L, Hohnloser $\mathrm{SH}$, et al. Left atrial appendage occlusion study (LAAOS): results of a randomized controlled pilot study of left atrial appendage occlusion during coronary bypass surgery in patients at risk for stroke. Am Heart J. 2005;150(2):288-93.

86. Whitlock RP, Vincent J, Blackall MH, Hirsh J, Fremes S, Novick R, et al. Left atrial appendage occlusion study II (LAAOS II). Can J Cardiol. 2013;29(11):1443-7.

87. Aoyagi S, Tayama E, Oda T, Kosuga T, Yasunaga H. Intra-atrial excision of the left atrial appendage: a simple and easy technique. Heart Lung Circ. 2017;26(4):413-115.

88. Bartus K, Morelli RL, Szczepanski W, Kapelak B, Sadowski J, Lee RJ. Anatomic analysis of the left atrial appendage after closure with the LARIAT device. Circ Arrhythm Electrophysiol. 2014;7(4): 764-7. 